\title{
Mentoring for Teachers' Competencies Development in the 21st Century
}

\author{
Wenhui Li
}

Guangzhou, China

liwenhui2018@gmail.com

\section{Key words: mentoring, teachers' competencies, e-mentoring}

\begin{abstract}
Mentoring plays an important role on developing teacher competencies in the $21 \mathrm{st}$ century. Through mentoring practice, teachers can not only gain knowledge, skill and attitude competencies, but also acquire professional development in the career path. The purpose of this article is to show how mentoring will enhance teachers' competencies in their workplace. The first part of the article is reviewing competencies of teachers in the 21 st century and lead to the topic. The second part is giving the concepts and definitions of mentoring, which will be told about the significance of the mentoring. The third part shows the strategies and steps for mentoring, which aims at developing and training teachers' competencies. There are formal mentoring model of apprenticeship, training, reflection strategies and e-mentoring model for improving competencies of teachers in the 21 st century. Although many models and approaches for mentoring practice, some favorable and unfavorable conditions of the strategies will be discussed in the fourth and fifth parts. Then the article will draw a conclusion for the whole topic.
\end{abstract}

\section{Introduction}

With the development of technology and globalization in the $21^{\text {st }}$ century, teachers should possess several competences in order to adapt in this changing environment. Based on different scholars' achievements, teachers' competences in the $21^{\text {st }}$ century can be divided into three categories: knowledge competences, skill competences and attitudes competences. (See Appendix) Some of the competences are also required in the past century, such as professional knowledge, pedagogical skill, social skill and etc. However, in the $21^{\text {st }}$ century socio-economic globalization, teachers require to have more competences in a high level, which accommodate themselves to circumstances and can teach students to become a competiveness person in the world.

It can be seen that teachers should hold many kind of competences. The purpose of this article is to develop these $21^{\text {st }}$ century teachers' competences so as to let teachers own their ability with high proficiency. There are many approaches for training teachers' competences. Mentoring has played an important part in teacher education. (Klung and Dalzman, 1991) In the article, it will choose mentoring for training and developing teachers' competences. Through mentoring, it can be trained and continued profession development for teacher education.

\section{Definitions and Concepts of Mentoring}

\subsection{What is mentoring?}

There are many scholars researched on mentoring beginning teachers to train and help teachers integrate into the workplace. In the past few years, mentoring has various definitions, which defined by different scholars. The original of mentor comes from Homer's epic poem, The Odyssey. (Kerry and Shelton, 1995)

According to Cluterbuck (2001), mentoring is a protected relationship with developed the potential skills, which lead to the result of acquiring competencies during the learning procedure. Mentoring is essential to profession development. Cohen (1995) defined that mentoring is a behavioral activity evolving between the mentor and learner, which develop and train the learners' personal or career potential. While in the field of education, Portner (2008) stated that mentors are normally some experienced teachers who guild the new teachers to profession, help and encourage 
the new colleagues to be better teachers with full of competences.

Another term is E-mentoring. According to Single and Muller (2001), E-mentoring is a relationship between a senior experience mentor and a new staff with little skills and experiences, using electronic communications to train and develop competences needed in their workplace.

During the mentoring process, another term 'mentee or protégé' will come occur. It refers to the person receiving the help guidance and support of a more senior, experienced staff member. (Mathews, 2003, P. 332)

\subsection{The importance of mentoring}

In the early years of the profession, teachers need assistance and guidance during the induction period. (Jonson, 2008) When realized the importance of mentoring, it is necessary for the schools or the education institutions to provide experienced mentors to guide the new teachers in the early years of their professions, which can help the teachers develop their competences as well as personal development.

Cunningham (1999) stated that mentoring in the induction time can help the new teachers to gain some competences and experience from the experiences teachers, which let the new teachers adapt well in their new working environment. According to Jonson (2008), mentors can help teachers know more about the culture of the school, which give them support and encouragement in the early period of their careers.

Teachers' competencies can be developed through mentoring. Mathews (2003) discussed that mentoring can enhance socialization, job competencies, future career prospects and etc. So, it can be seen that mentoring is essential for developing teachers' competencies in the $21^{\text {st }}$ century.

\section{Strategies for Mentoring Teachers Competencies in the $21^{\text {st }}$ century}

Mentoring plays an important role on developing teachers' competencies in $21^{\text {st }}$ century socioeconomic globalization. There are many mentoring model and strategies for training teachers' competencies. With the development of technology, it will be chosen both formal mentoring model and modern E-Mentoring model to develop teachers' competencies. Based on difference scholars of strategies of mentoring, the overall process of strategies in mentoring will show in figure 1.

Figure 1: Stages and process of the strategies in mentoring (Kerry and Shelton, 1995; Duncan, 2005; Single, 2005)

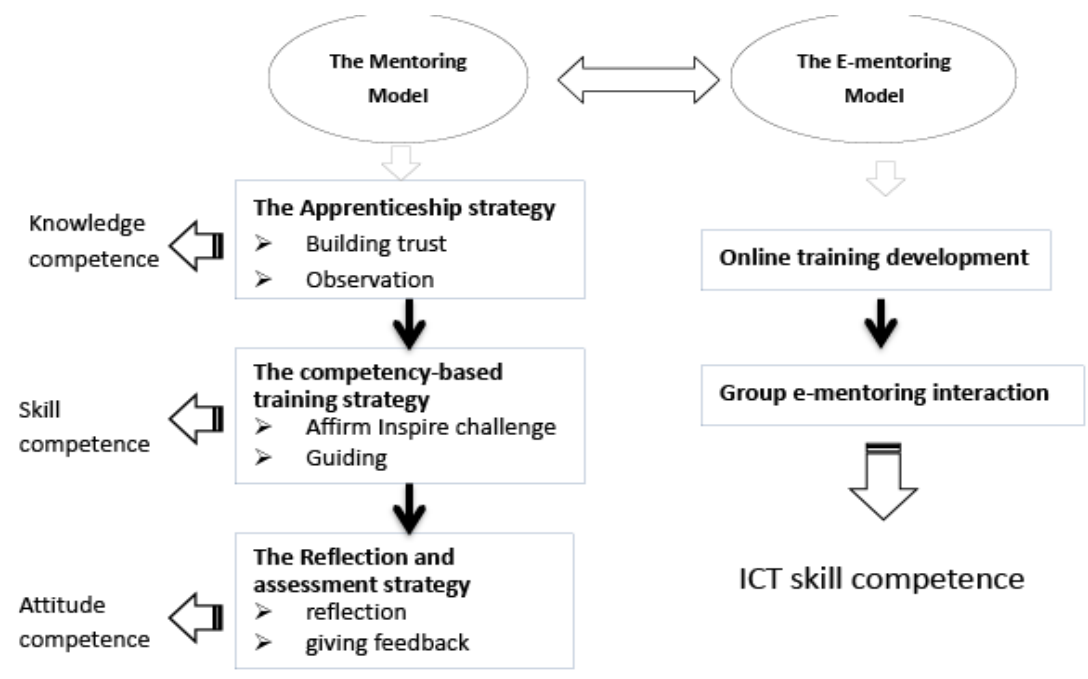

\subsection{The model of mentoring}

\subsubsection{The apprenticeship with observation strategy}

The apprenticeship is a way of learning to see and learning to teach, which is raised by Hillgate Group (1989). This is an early stage of mentoring, which let mentee to work alongside with an experienced mentor to take responsibility of the teaching process. (Kerry and Shelton, 1995) 
There are two steps for this apprenticeship strategy. First, mentors need to establish new identity of building trusting relations with mentees. (Lieberman et al 2012) Jonson (2008) pointed out that mentors should be an active listener rather than judge, analyze and question the mentees. Second, mentees should observe mentor's action for gaining knowledge from mentors. (Burn, 1992) During the observation for apprenticeship, mentees learn how to plan lesson and teach students. It is a sort of learning to see and teach.

After the apprenticeship with observation strategy, teachers can learn from their mentors to gain some competencies needed in the $21^{\text {st }}$ century. As we discuss before, knowledge competencies are necessary for teacher in the education institutions, which need to be broaden teachers' horizons in the knowledge-based society. Through observation, the teachers (mentees) can obtain much knowledge experience from mentors. Therefore, learning to see and teach is a way for developing and training teachers' knowledge competencies in the $21^{\text {st }}$ century.

\subsubsection{The competency-based with systematic training strategy}

Kerry and Shelton (1995) stated that the mentor plays a role on a systematic trainer in the competencybased strategy, guides and obverses the mentees of their behaviors in micro-teaching method.

There are two steps of systematic training strategy through mentoring. First, during this strategy, mentor can encourage mentees with affirming their protégés for what they can do; inspire them and challenge them with growing professional experiences. (Kerry and Shelton, 1995) Second, mentors take an active role to guide mentees' professional development. In this step, mentees need to be given control of the teaching process, which can let them take responsibility with actual teaching. (Ibid)

Through competency-based with training strategy, teachers can acquire many skill-based competencies in the $21^{\text {st }}$ century. After this strategy of mentoring process, mentees' will be guided with stimulation to improve and develop creative and critical thinking, helped to build the vision future situation. (Portner, 2008) By guiding to take control in the actual teaching process, mentees learn to adapt the changing situation with their innovation spirits. Therefore, systematic training through improving competency can develop and train teachers' skill-based competencies in the $21^{\text {st }}$ century, especially creativity and adaptability skill.

\subsubsection{The reflection and assessment strategy}

The reflection and assessment is the final approach of mentoring process. During this strategy, mentors will provide specific feedback by observing mentees' teaching, which help mentees improve their professional development. (Jonson, 2008)

There are also two steps of the reflection and assessment strategy. First, mentees are encouraged to switch from focusing on their own teaching performance to their students' learning ways, which need to be reflected by mentees themselves and made the whole process more effectively. (Kerry and Shelton, 1995) Second, Portner (2008) pointed out that assessing mentees' behaviors for ensuring that their professional needs and development are implemented. Mentors should give feedback for the mentees in order to have self-improvement by mentees themselves.

After the reflection and assessment strategy, mentees can shift from teaching to learning. According to Shulman \& Clobert (1988), mentors suggested that mentees should reflect on their own teaching, which give them life-long learning and improvement. As mentioned previously, teachers in the $21^{\text {st }}$ century education institutions need to possess attitude competences. Therefore, through deeper level of reflecting and assessing by mentors, teachers (mentees) will improve their attitude competencies, especially life-long learning competencies, which meet the requirement in $21^{\text {st }}$ century knowledge-based economy.

\subsection{E-Mentoring model}

According to the definition of the E-mentoring mentioned above, it is only using technology as a tool to complete the mentor procedure. Using technology in mentoring can adapt the changing environment in the $21^{\text {st }}$ century and provide convenience with high efficiency. According to Single (2005), the model of e-mentoring includes three approaches-planning, program structure, and 
assessment. The program structure contains training, coaching, and group e-mentoring in e-mentoring program. (Single, 2005)

\subsubsection{Online training development strategy}

Through online mentoring program, new teachers provide with video clips and other resources at any time to guide them with events happen in the classroom. They can discuss among those beginning teachers and share the view in the induction period. (Duncan, 2005) During this online training, the form of training consisted of grouping several new teachers on an electronic discussion list. Mentees will be presented with scenarios and information in e-mentoring system guided by experienced mentors. (Single, 2005)

\subsubsection{Group e-mentoring interaction strategy}

Group e-mentoring let all the new teachers benefit and encourage from others through using e-mail or other way to communicate with each other. Duncan (2005) stated that during the group e-mentoring, mentors can communicate with mentees through videoconference and create great environment for beginning teachers in order to adapt the culture in their workplace.

\subsubsection{Developing teachers' competencies in e-mentoring}

E-mentoring is using technology for guiding new teachers, which is really new model. Teachers in the $21^{\text {st }}$ century need to possess many skill competences. Information technology communication (ICT) skill is a new competencies need for teachers, which can be trained by e-mentoring. The beginning teachers will learn some technology through e-mentoring, such as discussion system, email interaction and etc. Therefore, e-mentoring is a suitable model for today's changing environment. It can be improved communication skill and developed ICT skill competencies for teachers in the $21^{\text {st }}$ century.

\section{Critical Success Factors for the Strategies}

When implement the strategies mentioned above, there are some favorable conditions for facilitate the effective and achievement of mentoring program. Some researches show that mentees' willingness to be mentored is the key element for the successful mentoring. (Valencic Zuljan \& Vogrinc, 2007)

The first favorable condition for the mentoring is contextual support for mentoring. Some researches show that the achievement of mentoring process and relationships is effected by the contextual factors. (Hobson et al., 2009) Bullough (2005) stated that successful mentoring can be facilitated between mentors and mentees to have support meeting during the working day. Because of the mentoring can take place in the working environment from the school or education institutions, it is likely to be successful for the apprenticeship strategy.

Additionally, Hobson et al (2009) pointed out that one of the successful factors is mentors' preparation and support. Some studies show that mentors have undertaken the program of mentor preparation for preform mentoring strategies well and effective. (Valencic Zuljan \& Vogrinc, 2007) Bullough (2005) stated that mentors need to be trained for the preparation in seminars, which can facilitate the professional development for mentors and enhance mentors' skill during mentoring practice. Therefore, mentors' great preparation and support will help and guide teacher mentees through all the strategies of mentoring program. It can ensure the effective and achievement of the strategies, which develop and train teachers' competencies in professional development.

Moreover, the successful factor of e-mentoring is that both mentors and mentees can communicate with each other and assess the resource at anytime and anywhere. Price and Hui-Hui (2003) pointed out that it can be conducted across no-restrict distance and flexible access regardless of time and space with larger and greater resources. The e-mentoring program with great technology can bring much more convenience for mentors and mentees. 


\section{Limitations for the Strategies}

During carrying out the strategies of mentoring program, there are some unfavorable condition restrict the mentoring procedure.

Firstly, it is engaging teachers' commitment. Higgins \& Leat (1997) stated that if the teachers mentees consider that they are being manipulated, they probability will not be accepted for the arranging the mentoring process with various strategies positively. The school management section needs to persuade their teachers of the advantage and benefits of the mentoring program, which will be a challenge. (Rhodes \& Beneicke, 2002) Teacher mentees are all adult learners. Brookfield (1986) stated that it is need to be aware of the unique learning styles for adult learners. Therefore, mentors should respect every learning style of the teacher mentees, which is hard to take balance during mentoring process.

Secondly, according to Rhodes and Beneicke (2002), time constraint is one of the limitations for the mentoring strategies. The time schedule of the mentoring practice will base on teacher workload. Due to the heavy workload of the teachers in the education institutions, there is not sufficient time for the mentors to undertake their role. Therefore, this is an unfavorable condition for implementing the mentoring strategies.

Additionally, during the competency-based training strategy in the mentoring process, once teacher mentees take control and responsibility in the teaching class, they will establish their own teaching styles and strategies. Then they may stop learning. (Kerry and Shelton, 1995) This will be limited the progressive of the professional development, which is not good for developing the teachers' competencies during the mentoring procedure.

Lastly, Bierema and Merriam (2002) discussed that there may be lack of equipment for accessing computers and virtual intimacy may be difficult to obtain through e-mentoring. Owning a computers will not be available for every mentors and mentees, which is great problematic for e-mentoring. During e-mentoring, mentors and mentees have meet virtually, which will take time for building relationship and will appear misunderstanding for each other. These are the unfavorable conditions for e-mentoring process.

\section{Conclusion}

Teachers in the $21^{\text {st }}$ century education institutions should possess knowledge, skill and attitude competencies in order to adapt the development in the society. It is necessary for teachers to develop and train the competencies needed their workplace. Through mentoring process, it can help to improve teachers' competencies. According to Jonson (2008), the role of mentors is to help teacher mentees enhance the knowledge, skill and effective teaching requires, which can guide mentees to build self-confidence and self-direction for their own professional development.

Through mentoring model, there are three strategies to help develop and train teacher mentees. The apprenticeship with observation strategy in mentoring can enhance knowledge competencies for teachers. The competency-based training strategy in mentoring can improve skill-based competencies for teachers. The reflective and assessment strategy in mentoring can develop teachers' attitude competencies. Moreover, e-mentoring strategy can train teachers' special skill of information technology communication (ICT) competencies.

All of the strategies of mentoring process have favorable and unfavorable conditions during implementation. It is necessary for both mentors and mentees make good use of the favorable conditions and tackle the limitations and problems that restrict for the effective of mentoring practice.

\section{Appendix}

Figure: Teachers' competences in $21^{\text {st }}$ century educational institutions (Erik Roelofs and Piet Sanders, 2007; Richard E. Boyatzis, 2008; Tyrone C. Howard \& Glenda R. Aleman, 2008; Dr Christine Coombe, 2014; Brun, M., \& Hinostroza, J. E., 2014; Michael Fullan and Geoff Scott, 2014; Long Huan, 2011; Luo Huang and Tan, 2011) 


\begin{tabular}{|c|c|}
\hline Knowledge & $\begin{array}{l}\text { 1. Academic and professional knowledge } \\
\text { 2. Multicultural knowledge }\end{array}$ \\
\hline Skills & $\begin{array}{l}\text { 1. Pedagogical model } \\
\text { 2. Social skill } \\
\text { 3. ICT skill } \\
\text { 4. Creativity and innovation } \\
\text { 5. Critical thinking } \\
\text { 6. Communication } \\
\text { 7. Collaboration and team work } \\
\text { 8. Marketing } \\
\text { 9. Interaction }\end{array}$ \\
\hline Attitudes & $\begin{array}{l}\text { 1. Emotional intelligence. } \\
\text { 2. Affective characteristic and personality } \\
\text { 3. Life-long Learning }\end{array}$ \\
\hline
\end{tabular}

\section{References}

[1] Ann Lieberman, Susan Hanson, Janet Gless (2012) Mentoring Teachers, navigating the realword tensions, Jossey-Bass a Wiley Imprint

[2] Brookfield, S. D. (1986) Understanding and facilitating adult learning, San Francisco: JosseyBass

[3] Bullough, R. V., Jr. (2005) Being and becoming a mentor: school-based teacher educators and teacher educator identity. Teaching and Teacher Education, 21, 143-155.

[4] Burn, C. (1992) Collaborative teaching, in Wilkin, M. (ed.) Mentoring in Schools, London: Kogan Page.

[5] Clutterbuck, D (2001) Everyone needs a mentor: fostering talent at work. CIPD, London

[6] Cohen, N. (1995) Mentoring Adult Learners: a guide for educators and trainers, Krieger Publishing Company, Malabar, Florida

[7] Cunningham, S. (1999) The nature of workplace mentoring relationships among faculty members in Christian higher education, Journal of Higher Education vol. 70(4), pp-441-63

[8] Duncan, B.A. (2005, fall) Using technology to support instructional mentoring. Reflections, 8(1), $8-9$

[9] Hal Portner (2008) Mentoring New Teachers, third edition, Corwin Press

[10]Hillgate Group (1989) Learning to teach, London: The Claridge Press

[11]Higgins, S. \& Leat, D (1997) Horses for Courses: what is effective teacher development? British Journal of In-Service Education, 23, pp. 303-314

[12]Hobson A. J., Patricia Ashby, Angi Malderez, Peter D. Tomlinson (2009) Mentoring beginning teachers: What we know and what we don't, Teaching and Teacher Education 25 (2009) 201216

[13]Kathleen Feeney Jonson (2008) Being an Effective mentor-how to help beginning teachers succeed, second edition, Corwin Press

[14]Klung, B. and Salzman, S. (1991) Formal induction v. informal mentoring: comparative effects and outcomes, Teaching and Teacher Education (3)

[15]Laura L. Bierema and Sharan B. Merriam (2002) E-mentoring: Using Computer Mediated Communication to Enhance the Mentoring Process, Innovative Higher Education, Vol. 26, No. 3, Spring 2002 
[16] Mathews, P. (2003) Academic mentoring: enhancing the use of scarce resources, Educational Management and Administration, vol.31 (3), pp.313-329

[17]Price, M.A and Hui-Hui, C. (2003) Promises and challenges: exploring a collaborative telementing programme, Mentoring and Tutoring, vol. 11(1), pp. 105-117

[18]Rhodes Christopher \& Beneicke Sandra (2002) Coaching, mentoring and peer-networking: challenges for the management of teacher professional development in schools, Journal of InService Education, 28:2, 297-310

[19] Shulman, J.H., \& Colbert, J. A. (eds.) (1988) The intern teacher casebook, San Francisco: Far West Laboratory for Educational Research and Development

[20] Single, P.B. and Muller, C.B (2001) When e-mail and mentoring unite, Creating Mentoring and Coaching Programmes, The American Society for Training and Development in Action Series

[21] Single, P.B. \& Richard M. Single (2005) E-mentoring for social equity: review of research to inform program development, Mentoring \& Tutoring: Partnership in Learning, 13:2, 301-320

[22] Trevor Kerry and Ann Shelton Mayes (1995) Issues in Mentoring, London and New York, the Open University

[23] Valencic Zuljan, M., \& Vogrinc, J. (2007) A mentor's aid in developing the competences of teacher trainees, Educational Studies, 33(4), 373-384 